\title{
Neoliberal Logics of Voice: Playback Singing and Public Femaleness in South India
}

\begin{abstract}
:
This article explores the impact of neoliberal logics of voice on the music-making and performance practices of female playback singers in the South Indian Tamil film industry. As singers whose voices are first recorded in the studio and then "played back" on the set to be lip-synched by actors, playback singers have been professional musicians and public celebrities since the 1950s. Their careers are governed by practices of voice cultivation and by modes of performance and public self-presentation, in the studio, on stage, and increasingly in mediatized contexts. Since the 1990s, neoliberal logics of flexibility, entrepreneurship and self-marketing have redefined the role of the playback singer and the way singers conceive of their work in both social and aesthetic terms. These changes have occurred within a broader context in which anxieties about globalization and expanding commodity culture are reflected in debates about the place of women in public.
\end{abstract}

Nowadays we should be called playfront singers, not playback singers. We are not in the back anymore. Anupamaa Krishnaswami, interview with author, Dec 2009.

One of the crucial insights of critical scholarship on neoliberalism highlights the way in which neoliberal regimes do not reject, but rather re-purpose prior understandings of the world and of subjectivity to make them amenable to the governing principles of market rationality. While others have examined the re-purposing of concepts like individuality and agency (Gershon 2011), this article explores this insight with regard to the category of voice. In classic formations of the liberal subject, voice was conceived as the vehicle of individual will, intention, and as a sign of the subject's interiority (Taylor 1992). The figure of voice reappears in discourses and practices generated since the 1990s by neoliberal logics in which earlier notions of will, intention and interiority are refigured as creativity, entrepreneurship, and self-management. In the neoliberal conjuncture, voice often functions as a trope for the prized values of "freedom," "creativity" and "communication" (Kunreuther 2010, 2006). How does such a figure of voice intersect with actual vocal practices in music-making contexts?

This article explores the impact of neoliberal logics of voice on the careers and musicmaking and performance practices of female playback singers in the South Indian Tamil film industry. Known as such because their voices are first recorded in the studio and then "played back" on the set to be lip-synched by the actors, playback singers have been professional musicians and public celebrities since the 1950s. They are an essential part of the popular film industries of India. Film songs, a central element of India's popular culture industry and its main form of popular music, are a means by which voices are powerfully linked to class, caste, community, gender, and regional/national identity. Playback singing is thus a realm of vocality that has become intricately encoded with meaning. 
At the same time, playback singing as a profession has produced new forms of stardom and new opportunities for women to enter the public sphere. Although they do not appear on screen, playback singers are celebrities in their own right; they are credited in films, and knowledge about them circulates through news, fan magazines, blogs, FM radio, and through their appearances on TV and in live stage shows. Their careers are thus governed not only by practices of voice cultivation and production, but also by modes of performance and public self-presentation, in the studio, on stage, and increasingly in mediatized contexts. Since the 1990s, neoliberal logics of flexibility, self-management, entrepreneurship and self-marketing have redefined both the role of the playback singer and the ways singers conceive of their work in social and aesthetic terms. These changes have occurred within a broader context in which anxieties about globalization and expanding commodity culture, crystallized in debates about the place of women in public and in media representations (Lukose 2009, Oza 2006), make decisions about how to look, sound, and perform particularly fraught for female singers.

\section{Playback Singing and Aural Stardom}

Playback singing emerged as profession in the decades following India's Independence, granted in 1947. From the 1950s to the 1970s, beginning with the leadership of Jawaharlal Nehru, India embraced a socialist model that involved the careful regulation of India's economy and protection against foreign capital. Nehruvian nationalism emphasized the importance of large development projects such as the building of dams, and saw domestic production and heavy industry as key elements of planned economic growth. Media such as radio and television were regulated by the central government. In an extension of colonial-era discourses of respectability and social reform, these media were treated largely as a tool of development that could promote national integration and provide pedagogical and wholesome entertainment. Cinema was viewed by the state as more prone to "vulgarity" and in need of constant oversight if it was to fulfill this pedagogical function (Ganti 2012, 48-58).

Cinema, and the culture industry that came to surround it, however, was central to the post-Independence project of defining women's place within a specifically Indian and Tamil modernity. In many films of the 1950s and 60s, a national-secular "modern" public sphere defined in opposition to ties of caste, community, and family was evoked by two gendered tropes: the imagination of the nation-as-mother and the pervasive trope of romantic love with its figure of the flirtatious but sexually contained woman. In the Tamil context, these tropes were additionally inflected by pride in Tamil language and culture as a way of defining a specifically Tamil modernity against the West, North Indian hegemony, and upper-caste domination. Anchoring this vision were a series of gendered imaginaries: the valorization of the self-sacrificing and nurturing mother, elaborated in the concepts of taymoli (mother language), taynadu (mother land), and taykulam (women as a "community of mothers"), and the elaboration of karpu (chastity) and the figure of the pattini (a woman loyal to her husband) in contrast to the prostitute or courtesan (Ramaswamy 1997, Lakshmi 1990).

In the 1940s, the film industries in India transitioned from using primarily singing actors and actresses to using the playback system (Indraganti 2012). By the early 1950s, a 
characteristic female playback voice had developed. The aesthetics of this new female playback voice were shared across the Bombay-based and South Indian film industries. While Lata Mangeshkar, and to a lesser extent her sister Asha Bhosle, dominated the field of Hindi films, in the South Indian context, from the 1950s through the 1980s, three or four female singers dominated the field and their voices were immediately recognizable and well known to the public. The female playback voice retained the melismatic virtuosity that would make it recognizably Indian, but otherwise, especially with regard to pitch and timbre, had little precedent in existing female vocal genres. Free of associations with courtesan, ethnic, folk, and even classical voices, the female playback voice had an appealing newness that could lay claim to the modern in a way that female voices from other traditions could not. The high pitch and thin timbre could signify both youthful, girlish flirtatiousness without the connotation of female authority or desire as well as the gentleness and purity of motherly love. The female playback voice that emerged in the 1950s and 60s can be interpreted as a solution to the problem of how women (both the singers themselves and the female characters in films) could appear in the newly defined public sphere while keeping their modesty intact (Srivastava 2006).

During this period, playback singing developed a distinctive form of celebrity, which Neepa Majumdar has termed "aural stardom"-a concept that was particularly salient for women who became professional playback singers (Majumdar 2001). ${ }^{1}$ The first professional female playback singers negotiated their potentially problematic publicness by adopting a distinctly non-glamorous persona that would distinguish them from the actresses for whom they sang, by developing a non-emotive stage performance style that seemingly dissociated them from the songs they sang, and by cultivating an ideal of vocal constancy and recognizability. At the same time, the figure of the respectable female playback singer was being discursively produced in the media through descriptions of the singers and their public performances. A brief examination of the voice and persona of P. Susheela (b.1935), the first female singer to achieve a dominance over female roles in Tamil cinema, and often described as the "Lata Mangeshkar of South India," illustrates the ways in which female playback singers of this period embodied the ideals of aural stardom.

Throughout the 1950s, 60s, and 70s, Susheela's voice, said to be as "sweet as nectar," with its high pitch and open timbre, was matched with thousands of female characters in Tamil cinema who embodied a range of types, from chaste respectable womanliness to youthful, girlish flirtatiousness (but stopping short of vamp characters, whose voices were usually provided by another playback singer). Despite her large repertoire of songs and multi-decade career, Susheela herself, and other singers and music directors with whom I spoke, emphasized the constancy of her voice across different characters. ${ }^{2}$ A poem written about her by a Tamil writer and radio personality compared her to "a sparrow who does not know how to change her voice for different stars like TM Sounderarajan does [a male singer with whom she was often paired]; for all it is the same voice only! Even so, without dancing or moving as she stands and sings, it is as if Padmini is singing, as if Savitri is singing... [names of actresses] (Sudakar). 
This quote encapsulates several important aspects of playback singing as a cultural phenomenon and in particular what it meant to be a respectable female playback singer in the 1950s, 60s, and 70s. The implication is that while male actors and characters were individuated by different voices, actresses stood in for a general type who could always be given the same unvarying voice. The comparison of Susheela to a bird echoes earlier discourse about women singers, suggesting an absence of intentionality: the "naturalness" and innocence of a voice that "does not know how to change," paired with a body that does not perform. We can see the different standards of authenticity applied to male and female singers here as well. T. M. Sounderarajan, who sang for a range of male characters from the 1950s to the 1980s, was well known for his ability to "become the hero" by changing his voice depending on whether he sang for Sivaji Ganesan or M.G. Ramachandran; Susheela was praised for exactly the opposite: an apparently effortless constancy both in voice and bodily comportment.

In 2002 I accompanied Susheela to a wedding in which she had been booked to give a live concert of her songs with a backup orchestra. Throughout the performance, she stood immobile before the microphone, eyes focused on the music stand, with the end of her silk sari draped carefully over her right shoulder: a stance that has become iconic of the respectable female playback singer. Confounding western expectations of an "expressive" performance, this mode of performance operates by a different logic. Fans often describe their favorite playback singers from this generation in divine terms. As one audience member put it to me, "we come because we want to see the source." In this sense and in the stillness of the singer's posture, it is akin to the practice, elaborated within Hinduism, of receiving darshan from a divine being. The meaning of the event is not in the performance but in the very fact of the singer's presence on stage, which might in fact be compromised by too demonstrative a performance.

\section{Liberalization and its Implications}

The idealized female playback vocal sound and stage persona which I have discussed so far held sway until the 1990s when, in the aftermath of economic liberalization, the emergence of privatized media, the increased importance of advertising and consumption, and the rise of the new middle class introduced new gendered possibilities. The liberalization of India's economy began with policies and discourses that emerged in the 1980s. Under the leadership of Rajiv Gandhi, import regulations were loosened to allow the entry into the Indian market of consumer goods that could cater to middle- and upper midde class tastes (Fernandes 2006, 37). The process of liberalization was accelerated with the adoption of the New Economic Policy (NEP) in 1991, which decreased the restrictions and controls that promoted state monopolies, reduced customs duty on electronics, lessened controls on manufacturing consumer goods and their prices, lowered taxes, and made it easier for non-resident Indians to remit money, effectively opening the Indian economy to global capital (Nakassis 2010,7; Jenkins 1999; Rajagopal 2001). The resulting increase in available consumer goods, both foreign and domestic-made, was accompanied by an explosion of privatized media that brought in images and sounds from abroad and provided alternatives to state-controlled radio and television while giving increased scope and prominence to the advertising industry (Fernandes 2006, Mazzarella 2003, Rajagopal 1999). 
Several broad cultural effects of liberalization are especially pertinent to the context I discuss in this article. The emergence of the "new middle class" under liberalization was intertwined with the ideal of what Ritty Lukose has termed consumer-citizenship, a formation in which access to the public sphere and to recognition by the state is achieved through commodity consumption and one's ability to acquire and properly display particular brands $(2009,7)$. Consumption-based class distinctions emerged between members of the new middle class and both traditional elites and subaltern groups, distinctions that were also expressed through language. Membership in the new middle class meant having command over English and a specifically hybridized form of language in which not only English vocabulary, but English grammar and syntax were mixed with the use of Indian languages such as Hindi or Tamil, exemplified by the chatty "veejay" style that can be heard on television, radio, and stage today (Fernandes 2006, 69).

Within this formation of the new middle class, the iconic figure of the "new Indian woman," as an urban, upwardly mobile consumer of Indian and Western commodities, became a source of both celebration and anxiety. "In contrast to the more docile and homely figure of the Bharatiya nari (traditional Indian woman), this new woman was aggressive, confident, urban, and she displayed a sexual identity that had previously been associated with 'vamps' in Bollywood cinema... She reflected the nation's evolving political economy and newly open borders" (Oza 2006, 22). Blurring formerly clear boundaries between "respectable" womanhood and the figure of the vamp or courtesan, the figure of the new Indian woman in the 1990s and the 2000s has been accompanied by multiple public debates about sexual exploitation, obscenity, vulgarity, and the need for censorship (Oza 2006, Mazzarella 2013).

Liberalization has also affected the film industry in India in ways that have direct implications for all those associated with it. In 1998, after years of governmental disapproval, the Government of India granted industry status to commercial filmmaking, citing it as an engine of economic growth through its generation of revenue and its global circulation. Instead of being condemned as a disorganized and shady underworld that churned out trashy films, the film industry was lauded as a symbol of "native ingenuity and success" (Ganti 2012, 75). This resignification of the film industry, Ganti argues, is an important aspect of its "gentrification," a shift that has accorded filmmaking, acting, and other film-related roles, such as music director, playback singer, and sound engineer a level of legitimacy and a sense of artistic agency that had not existed in earlier periods.

Even more specifically, the decentralizing effects of economic liberalization were felt in two major changes that affected the field of playback singing in the 1990s. One was the shift from the dominance of a few singers at any one particular time to competition among many. The other was a shift, enabled by multitrack digital recording, from recording film songs almost entirely at two big studios in Chennai to recording in many newly opened small studios around the city. These have led to changes at the level of vocal sound, performance practice, and discourse about music-making. Music directors began to seek out new and varied female voices and new kinds of performers. In the 
liberalized field of playback singing, the dominant ideal of the playback singer as icon of female respectability gave way to a new value placed on singers with varied vocal timbres and styles. It became important for singers to chat with the audience between songs and establish a personal style through performance, dress, and other, non-playback musical activities. The remainder of this article will consider some of these shifts in more detail, their implications for public femaleness in contemporary India, and what they might suggest about ideologies of voice in neoliberal times.

\section{New Age Personas}

Perhaps no figure better exemplifies these shifts than A. R. Rahman, the South Indian film music director who began as a keyboard sessions player in film studios in Chennai, gained visibility through his adverstising jingles in the late 1980s, made his mark in Tamil cinema in the early 1990s, achieved national visibility in the late 1990s, and then transcended the role of film music director in the 2000s, becoming known as an internationally celebrated and Oscar-decorated world music composer (Mathai 2009). A new kind of sound in Tamil film music emerged in the early 1990s as Rahman gained popularity. The lush string orchestra sound and use of Tamil folk and Karnatic classical music that characterized the sound of prevailing music director Illayaraja in the 1970s and 80s gave way to music that sounded different and resulted from a different production process. "New age" music directors - a label reserved for Rahman and those who have come after him - stopped relying on the large string orchestra for their basic sound. Using with digital synthesizing technology, they sampled new instrumental sounds and vocal styles from around the world, and used repetitive dance beats and harmony. They sought out a wider variety of vocal timbres and capabilities, employing singers with different kinds of training and musical backgrounds, particularly singers experienced in Hindustani classical and Western pop styles. Film songs of this period, influenced by the chord-and riff-based structures of Indipop, moved away from earlier raga-based compositions, and increasingly began to use non-verbal vocal expressions, such as vocables, nonsense words, English, and other non-Tamil lyrics (Getter and Balasubrahmaniyan 2008; Sarrazin 2008; Booth 2011; Kvetko 2004, 184).

These changes enabled the emergence of a new vocal sound and persona for female playback singers in the 1990s. The singer Anupamaa Krishnaswami is often cited as a pioneer in this regard, particularly through her hit song "Konjam Nilavu" from the film Thiruda Thiruda (1993). As did a whole generation of playback singers who came up in the late 80 s and early 90s, Anupamaa entered the field of playback through her work on advertising jingles with the young A.R. Rahman. She had grown up in New Delhi listening to Western pop-Whitney Houston, the Carpenters, and the Beatles - and had only perfunctory training in Karnatic music. Rahman at that time was looking for "different" voices, Anupamaa recalled. " If I had sounded like Chitra or Susheela [established older playback singers], I wouldn't have gotten the chance."

Her training as primarily a rock/pop singer is audible in "Konjam Nilavu," which features a female voice varying widely in timbre - breathy here, cracking there, sometimes grunting, with audible inhales and exhales. Anupamaa also uses vibrato, which marks her voice as "western" in this context. Her vocal sound is distinctly unlike the smooth, 
consistent, vibrato-less timbres of earlier female singers, which were only occasionally interrupted by stylized laughing, crying, or sighing "effects" that were inserted into the songs of the 1950s-70s but kept separate from the singing voice. Anupamaa described the change in what is allowable in the female voice in terms of increasing freedom: "It used to be that if there was any grunt in your voice they would say something is wrong," Anupamaa told me. "Even 'sexy' singers like Asha Bhosle and L.R. Eswari could only vary within a small range of what was permitted. Now there are fewer restrictions."

The song is, in the typology often quoted to me, a "Western number," (a modern version of the older "cabaret" style song made prominent in Indian films of the 1960s and 70s) in which the beautiful, rich - but not entirely good - dancer Chandralekha's character is introduced. Dancing in a palace before a seemingly international audience ${ }^{4}$, Chandralekha describes herself as a play of contrasts, singing against a disco beat with operatic female voices floating in the background:

Konjam nilavu, konjam neruppu

Ondraaka serndaal endan tekam

Konjam nanju, konjam amudham

Ondraaka serndaal endan kangal

Konjam mirugam, konjam kadavul

Ondrai serndaal endan nenjam

Chandralekhaaa....

a little moonlight, a little fire, mix them and that's my body; a little poison, a little ambrosia, mix them and those are my eyes; a little animal, a little divinity, mix them and that is my heart/soul. Chandralekhaaa....

Not only the timbre of Anupamaa's voice, but also her performing style in live renditions of the song set her apart from the older aesthetic cultivated by female playback singers. In her live performance of this song at Rahman's Chennai Unity of Light concert in 2002, Anupamaa wore a figure-hugging gown and danced as she sang, taking possession of the stage in a way that visually evokes the song scene in the film. She sang in a dramatic and exaggerated way on stage, popping her p's and grunting out the word for "animal" in a voice that threatened to go out of control at the end of every phrase. ${ }^{5}$

"There is a big connection between playback singing and acting," Anupamaa told me. "I'm more of an actor when I sing. Very emotional. I use my hands and my whole body. It's pointless to perform as if you're in the recording studio-then people may as well listen to the recordings. Nowadays we should be called playfront singers, not playback singers. We are not in the back anymore." It is notable that Anupamaa collapses playback singing and acting into the same category here. The way in which young singers use dress, gesture, and movement on stage to evoke the song scene and 
particularly the image of the actress in the film directly contradicts earlier singers' strategy of distancing themselves from the actresses for whom they sang.

Another trend that is in direct contradiction to earlier singers' strategies is for playback singers to identify themselves with their hit songs. Singers of Anupamaa's generation and younger speak of needing to "feel connected to" the songs they sing, and they use these songs to present themselves as singers to audiences outside of the playback context. Anupamaa described a new album she is working on, which will be titled "Konjam Nilavu Konjam Neruppu," and will feature her singing in different styles ranging from rock, jazz and salsa to songs inspired by Tamil folk music. "A little moonlight, a little fire," the words of the film song, refer in this context to the singer, not the character in the film. Although lines from film songs have long been used by recording companies to title compilations of playback singers' songs, here the difference is that the film song is being used by the singer herself to describe and present herself as a creative (rather than merely reproductive) artist who transcends the world of film music.

This emerging ideal of the playback singer as creative artist goes along with a marked change in India's music production after liberalization: the emergence of and increasing attention given to popular music outside of film music. Pop music produced in India (known since the late 1980s as "Indipop") sonically and ideologically distinguishes itself from film song, promoting itself as a genre that values creativity, independence, individuality, and freedom in contrast to the formulaic, mass culture-oriented film song (Kvetko 2004, Zuberi 2002). It does so through lyrics and sound, but also through its presentation of the singer as a "self" voiced in the songs. In the business of Indipop, Peter Kvetko writes,

the consumer buys an individual personality with each record. This is at odds with the world of Bollywood, and it seems to present a challenge to the authenticity of the entire system of playback singing. Cosmopolitan viewers often complain that typical Hindi films rely on traditional roles in a stereotypical, cookie-cutter fashion. The producers and marketers of Indipop fixate themselves on product distinction, individual style, and selling the notion of self-expression $(2004,186)$.

The first pop album to be released by a playback singer in the Tamil context was Anuradha Sriram's Chennai Girl, in 1997. It heralded a new kind of persona for female playback singers, articulated in the album's most popular song, "Modern Ponnu" [Modern Girl]. Beginning with the sounds of English being spoken, drinks being poured, and applause (aurally evoking the context of a club or five-star hotel, perhaps, but definitely not a light music show or a cinema theater), the song does away with the orchestral background and melismatic vocal lines characteristic of film songs. To a disco-like beat, interspersed by shakuhachi riffs that give the song a "world music" feel, Anuradha's high-pitched voice sings, "I am a modern ponnu, Tamil pesum modern ponnu" - "I am a modern girl, a Tamil-speaking modern girl, who doesn't shy away from new things, who has knowledge, conscience, culture, and love..." The song juxtaposes the English word "modern" with ропnu, the Tamil word for girl, and with a series of 
other properly Tamil word-concepts such as arivu [knowledge], manam [mindfulness, conscience], panbu [decency, cultured upbringing], and anbu [capacity for love, affection] which are often used to distinguish Tamil culture from the ills of modernity. In so doing, the song announces the possibility of a new subject - a girl who can speak Tamil and yet be modern, who can be cultured in traditional ways and yet also sing as herself before a listening public.

Anuradha embodies a new kind of playback singer, one who is competent in different musical traditions, both popular and classical, comfortable with glamour and accustomed to appearing on stage and TV (she started her own TV music game show, Antakshari, in 2001). Her English education, US graduate degree, as well as her love marriage to a Karnatic musician with whom she also performs, afford her a cosmopolitan identity. She is also highly sought after as a singer for specially-themed stage and TV shows. At a New Year's 2010 stage show I attended in Chennai, Anuradha was the lead singer in a special program featuring "romantic songs." Between songs and blaring advertisements for fancy consumer goods, the MC would call up a couple from the audience and ask whether they had a "love marriage or an arranged marriage." After engaging in some banter about this topic, the couple would pick a slip of paper out of a bag to determine the next romantic song to be sung by Anuradha. The show, built around the concept of romantic love, interpellated its audience as cosmopolitan, modern consumer-subjects with Anuradha as its idealized voice.

\section{Standards of Authenticity}

In India, liberalization has brought with it shifts in gender ideology and new gendered personae. In the 1950s the figure of the female playback singer was constructed in relation to a contrast between two types, the respectable family woman and the overly Westernized, sexually loose woman - the vamp. Now there is a third type, heralded by the cosmopolitan "modern girl" voiced by Anuradha in the 1990s, that young singers may embody. The vocal sound and performance practices that accompany this new persona are governed by new standards of authenticity that involve the "self" in two distinctively new ways: first, through a discourse of creativity and emotional involvement with the act of singing, and second, through the projection of a social and accessible self in work contexts and on stage.

In the older idiom, the authenticity of the playback singer's voice and persona was based on voice recognizability, an ideal that depended on cultivating a consistency of voice across many songs, having thousands of songs to one's credit by virtue of the dominance of two or three singers, and not moving around on stage while performing - indeed, demonstrative performance that drew attention to singers' bodies could interfere with the divine qualities ascribed to their voices. Young singers, by contrast, can't and don't aspire to singing thousands of songs like the older singers did; they view this negatively as "mass production." Instead, "they are all just hoping for a single hit that will make them famous," a young music director remarked. The ideal of voice recognizability has lost its salience; previously associated with divine inevitability, it is now negatively tinged with automaticity and formulaicness. 
Since A. R. Rahman's rise, a large number of singers have been introduced into the playback field. "Now you can't tell who is singing at all. Even in a single song there will be four or five singers," lamented an older music director, referring to Rahman's practice of combining and juxtaposing different vocal sounds. And because voice recognizability is no longer particularly valued, there is no longer the same emphasis on consistency as there used to be. Instead, the emphasis is on being able to sing in different styles (for example, rock, jazz, Hindustani). This is one way in which singers project a cosmopolitan image. The young singer Chinmayi proudly told me that "all my songs sound different-you wouldn't know it was the same singer in all of them."

An older discourse of reproduction, in which the singer was imagined as a kind of playback technology herself, has been replaced by ideas of "creativity" and "freedom" that emphasize the singer's status as an intentional and emotionally engaged artist. Many young singers talked about the importance of having "an emotional connection" to the film songs they were singing. Singers of Susheela's generation, by contrast, use the term "bhavam," a category borrowed from ways of talking about Karnatic music to describe the emotion or sentiment expressed in a song or raga; for example, in performance one "brings out the raga bhavam." In the discourse of bhavam, the emotional quality is inherent in the song or raga, and it is simply the singer's job to bring it out; the emotion is not the singer's own. When young playback singers speak of "feeling connected" to the songs they sing, however, they are stressing the need for their voices to be biographically embodied: to somehow reflect their own lives or emotions.

This may be why it is extremely common now - almost required, in fact-- for playback singers to produce independent albums or to be part of a band. Part of the reason for this is that with the expansion of the field of playback singers there is less work for any single person. But equally important is that these are genres that represent the artist as creative and emotionally invested in her or his music, an identity quite different from that of the traditional playback singer who was merely the "voice" for a song composed by somebody else. A young singer explained the appropriate ways playback singers could diversify: "In [my mother's] time, playback singing was a much-in-demand job-you could do it as a profession. Now you have to look at other areas also, you should cut your own albums, you should do alternative music, you can do your own shows with your own band and stuff like that."7 Although these are not particularly lucrative activities for most, they are important for young singers who feel that "we need to come out and present our own stuff too... All of us want to express ourselves. We can't do that with film music."

Most young singers talk about film music as being restrictive. "In playback, music always takes the back seat. Whereas in independent music or Western pop the music is the front thing. I want to do music from the front. I have had enough of doing it from the back... I'd like to go back to my band. We were so independent. When we came up with a song, we jammed. We never worried whether it was going to suit this or that person, or are the lyrics going to match, it was just the flow.... So open. The sky's the limit. I loved that element of no boundaries." "If older singers looked to classical music as a source of prestige, for these young singers, the band, and particularly the act of 
"jamming," is what confers value; it is considered the place where one's true musical self emerges. In 2009, during a ride home with a young singer after her performance at a college show, I was privy to her complaints about another playback singer who had performed; according to her, he had refused to come to any practice sessions and then just got on stage and did whatever he wanted. The problem with so many playback singers, she said, was that "they don't have a band mentality, where you come for practices and work together and jam together. They just keep on giving that kacceri sound." Literally translatable as "concert sound," this is a reference to Karnatic classical musicians who rarely practice together before stage performances. In her parlance, "kacceri sound" was shorthand for performances that were bound by tradition, where performers got up on stage and automatically did the same thing each time.

Similar notions of musical creativity and working together, encapsulated in the idea of "jamming," are used to describe the way "new age" music directors work. A singer who has had experience working with older and younger music directors contrasted the process of older music directors like M.S. Viswanathan and Illayaraja, who "tell you what they want and you have to sing exactly how they want it," to that of A.R. Rahman, who will "let you just sing," and record seven or eight versions. ${ }^{10}$ "Rahman likes to get the singer in their natural space and then just let them do their thing and improvise," another music director told me. ${ }^{11}$ Time in the studio that used to be devoted to learning and rehearsing an already composed song is now more often given over to experimentation, in which the singer's role as an artistic and intentional subject is, perhaps, more acknowledged. But coexisting with this increased scope for creativity in the studio is the fact that the singer's voice is increasingly subjected to digital manipulation after the tracks are recorded. As the singer Chitra told me, "now we have no idea what the song sounds like until we get the CD." At the end of a recording session I observed in December 2012 in which each line had been separately "punched" in multiple takes, the music director instructed the singer to take the whole song from the top and "do whatever you want-lyrics or humming. I'll take whatever is nice."

Recording sessions do not yield "songs" but rather flexible sets of sounds that can be combined and recombined later.

If new standards of authenticity demand that singers now think of themselves as creative, artistic, and intentional, there is also now a new value placed on the outward projection of oneself as accessible, both to the audience and to one's colleagues. Being sociable in the studio and on stage is a requirement; it is part of marketing oneself. In order to stand out in the crowded field of playback now, Anupamaa explained, "you have to sell yourself, be very pushy, and have a 'different' sound. It's easier to get opportunities as a playback singer now, but harder to stay there." The new value placed on sociability goes along with new vocal styles and modes of dress for female singers. In the course of an interview, a middle-generation singer who had risen to prominence in the 1980s and early 1990s vividly described these interrelated changes in vocal sound, appearance, and interactional norms. I quote her here at some length:

In my time, if a film had six songs, five would be melodic, and the sixth would be the vamp song. But nowadays, the vamp has been removed, the 
heroine wears all the vampy clothes and five out of the six songs are vampy item numbers. So you have ... alto voices, that is the kind of voice timbre you'll find on the FM channels today. Janaki, Chitra, Susheela were all head voices. Now they are more chesty, more throaty.... In those days the singers would come in lovely Kanchipuram saris, and they would put the pallu [end of the sari] over their shoulder. Then in my time we started wearing salwar khameez. Now they wear little spaghetti shoulder tops.... In those days I'd say 'Hi.' The generation before me would say 'Namaskaram.' ${ }^{12}$ The generation now is like 'Machchaaa ${ }^{13}$ ! How are you sweetie pie!' and lots of tactile contact. ....And parameters - we definitely had a fence which nobody could [cross]. We'd never socialize you know. Once we finished our work, we'd come back. Nowadays once the work is over they'll go out to a pub or chill out somewhere. More than a music director or singer, they're friends, pals these days. A huge shift has happened. ...It's like, you hang around, and if you get a song you get a song. In a studio, there'll be an office outside. 'Hey machchaa where are you da?' 'Hey I'm sitting outside.' The music director comes and says 'Hey I need a couple of voices.' In those days, an orchestra-in-charge called you, you went at a particular time, learned the song, you went inside and finished your work and came home. ${ }^{14}$

Older singers recalled P. Susheela arriving at the recording studio in a car, finishing her songs while the car waited, and then leaving. Whereas earlier a female singer's refusal to socialize connoted her respectability and was positively valued, it is now seen as a negative. This is a problem for young female singers who haven't mastered the art of "hanging out" either in the studio, which is a male-dominated environment, or on stage. "Some of the [young female] singers are having proper traditional values," a young male singer explained when I asked him what issues he thought female singers faced. “They're not like 'hey'... they can't do that. It doesn't come naturally to them.... Going on stage and just doing whatever you want is not something you can do immediately. Maybe abroad but not here." 15

Recognition in the crowded field of playback singing requires the projection of a consciously artistic and intentional, but also accessible self in public, exemplified in young singers' social and chatty presence on stage. Playback singers now model themselves on television "veejays," with their chatty, English-speaking style and fashionable clothes. The singer's speaking voice is part of her performing persona; she is expected to have something to say about the songs she sings. "I tell about the meaning of the song, or talk about how it was recorded in the studio," the young singer Chinmayi told me. Young singers pepper their performances with greetings and exhortations to the audience: "Hello Chennai!" or "Let's have some claps!" Such utterances function in what Roman Jakobson termed the phatic mode: establishing and remarking on the channel of communication itself rather than exchanging information (Kunreuther 2006, 340 ; Jakobson 1987,66$)$. In contrast to older singers who rarely spoke more than a few words during stage performances, these phatic utterances establish the singer as an accessible entertainer connecting with her audience, At the same time, the audience is, 
through its invited responses, being fashioned as a public centered around the singer, one that is accessible to the singer as well.

\section{The Politics of Performance}

Most importantly, new standards of authenticity demand that the singer's appearance and performance now match her voice. Female singers need to be willing to some extent to "act the part": to dress in ways that evoke the on-screen characters their voices represent in the films, and to move and gesture when they sing. All of the young singers I talked with conceptualized the field of playback singing as divided between two types: "stationary singers" who "just take the mic and stand there looking at the lyrics," and "performance-oriented singers" who can "rock the stage" and "pull the crowd in." This leaves many young female singers in a predicament, for as Chinmayi remarked to me, it is really quite difficult to move and gesture like a western pop star while singing a technically challenging Tamil film song. "I'm still experimenting with how to present myself on stage. We have no models of women who move around and sing, and no training in it," she explained. Performing in the neoliberal dispensation entails not simply a natural letting loose of previously hidden emotion, but rather a re-education of the body for public performance.

This became clear during an episode of the TV reality show "Airtel Super Singer Junior," an extremely popular singing talent hunt for children ranging from ages 6 to 14 from all around Tamil Nadu. Broadcast by Vijay TV, this is one of a spate of singing contest reality shows, loosely modeled on American Idol, which have emerged since the early to mid-2000s, offering season winners lucrative prizes such as cars, real estate, and of course the possibility of becoming a playback singer for films. Each episode has a different theme - for example, "moon" songs, old songs, remixes - and is judged by a panel of three playback singers. The contest season lasts almost a year and is closely followed by audiences. Several people I spoke with at a recent filming of an episode of Airtel Super Singer Junior remarked on the affective power of this show in particular; because it featured children, viewers followed it more avidly and were more invested in the results.

One round of the show, in March 2012, dubbed the "performance round," produced a particularly contentious decision. The pretense of this episode was that the contestants were to be judged on their "performance" of the song, not just their singing of it. They need to "sing, dance, perform, show their talents," the MC explained at the beginning. The special guest for the episode was the rapper and Indipop singer Baba Sehgal, introduced at the beginning as a "super performer." At one point in the show, he praised the performance of a contestant who was dressed in jeans, a leather jacket and a chain by calling her "a Britney Spears."

Later in the show, a contestant named Srisha, demurely dressed in a skirt that reached below her knees, sang "Kalasala," an item number song from the 2011 film Osthe. She sang with obvious command of the song but engaged in only a minimum of movement. The MC kindly asked Srisha if she "got nervous" or "forgot" her steps, to which she answered innocently, "no"- as if she had no steps to forget. The judges called on Baba 
Sehgal to advise her on how to perform. "It's not about dancing," he said. "Don't think that you have to dance. Think that you are the queen. Just walk," he continued, striding around the stage. "Connect with the audience. You're the winner. That's also performance." Srisha was given the chance to sing again; she took a few awkward steps back and forth this time. One of the judges told her, "You should get your parents to put you in a choreographic class. It'll really help you. Because you're a fabulous singer." Srisha was eliminated at the end of the round.

Audience members' comments show the tension between this new value placed on "performance" and notions of gendered and classed propriety and respectability. "An adolescent child cannot dance on the stage in the name of performance," wrote one. "Srisha is a good singer and has come from a middle class family," wrote another. "Is that the reason to eliminate her?" Another called it "the worst decision in music i have ever seen... If dancing is need[ed] for performance, $i$ have never seen singer chitra dancing in any stage performance... Actually singing without dancing is a talent_ according to tamil epic seevaga sinthamani. because for music our body will automatically dance for the beats. a singer should overcome the distraction and the singer should only concentrate in singing" [sic]. ${ }^{16}$ Invoking older schemata of value that privilege singing over dancing and acting, this last comment draws attention to the contrasting figures represented by Baba Sehgal, the performance "expert," and the playback singer Chitra, one of the judges on the show who embodies the older style of playback singing. Another judge on the show remarked to me that no one could outdo Chitra in singing, but that her comments to the contestants were always confined to "scratches and srutis," the specifics of vocal sound; she had nothing to say about the emotional aspect of songs or performing more generally.

\section{Neoliberal Logics of Voice}

We can identify several dynamics of neoliberalism at work in the shifts I have been describing. Most immediately apparent are the structural changes engendered by decentralization: the shift from recording at two large studios to a more fragmented process taking place at many small studios around the city, and the change from a field dominated by two or three singers at a time to one in which many singers are competing for work and face pressure to diversify their activities. Playback singers are now part of a labor force that is more flexible and more entrepreneurial than ever before. In this article, I have been concerned with the musical and subjective effects of these structural dynamics, particularly for female singers. What new kinds of voices and performing subjects are emergent in this context?

The notion of flexibility is apparent in the value singers now place on being able to sound different in different songs, and in diversifying: being able to sing in different genres, not only as a playback singer. In a very concrete sense, flexibility means a flexible voice and body - one that sings in different styles and genres, jams in the studio rather than singing a song from start to finish, one that moves on stage, that "vibes" and "connects" to the audience rather than standing rigidly. Such flexibility is a requirement in a field in which many singers are now in competition and face pressure to "sell" themselves to music 
directors and audiences. The value placed on a chatty, accessible persona is perhaps the clearest manifestation of neoliberal notions of personhood that rely on the trope of voice as an index of personal uniqueness, presence and emotional connection, bolstered by practices of speaking that seek to project spontaneity and sincerity (cf. Kunreuther 2010).

Meanwhile, the fetishization of "performance" and "connecting with the audience" apart from singing or dancing strongly evokes the neoliberal discourse of "soft skills" (Urciuoli 2008, 215), the inculcation of which becomes the province of new kinds of "experts": not singers or dancers in particular traditions, but "voice experts" and "super performers" who are seen as transcending divisions between traditions and genres (cf Chakraborty 2011). ${ }^{17}$ This marketing of skills apart from traditional genres is very much part of the neoliberal moment in India, where the cultivation of "personal" or "life" skills is often couched in terms of freeing oneself from the restrictions of tradition. ${ }^{18}$ Indeed, it has made possible the emergence since the mid 2000s of the entrepreneurial figure of the "voice expert," as distinct from one's teacher or guru who might train one to sing Karnatic or Hindustani classical music. It has also enabled the "voice" itself to be something that can be considered apart from its singing in a particular style or tradition. The voice expert on Airtel Super Singer Junior said he preferred working with people who had had no prior training, because there was less need to undo conditioning they had received from learning music. "Karnatic [music] especially is a very conditioning process. Very ethnic... But when the person is free, [they] come as an open canvass of abilities." ${ }^{, 19}$ This comment, to me, captures the new realities of the neoliberal dispensation, in which the high-cultural classical tradition that previously set the standard for musical value and discipline is now reduced to one "ethnic" conditioning process among others, and in which freedom and flexibility are combined in the idea of the untrained voice as an "open canvass."

Regimes of aurality and the voice are central to the creation of modern social formations. Precisely because they are generally unarticulated, operating at the level of embodiment and affect, they form the basis on which much discursive and visual meaning is generated even as they fall below the radar of discursive/visual regimes of knowledge and representation. Regimes of aurality and the voice influence fundamental aspects of subjectivity, including how we conceive of the self, intentionality, agency, and power. Beyond the structural changes that neoliberalism introduces, then, we can identify a neoliberal regime of voice which now governs how the role of the playback singer is defined, and how singers conceive of the work of singing in social and aesthetic terms. This neoliberal regime of voice entails a set of assumptions and demands which singers of earlier generations did not face. It involves a set of modern ideologies of voice, with their insistence on voice as a direct medium for expressing the inner self, which can be summed up in the following premises:

The singer's performance reflects her creativity and intentionality.

The singer has an emotional and biographical connection to what she is singing.

The singer's appearance and voice must match.

The song and the performance are a way for the singer to communicate to the audience about herself. 
At the same time, neoliberal logics of voice emphasize flexibility in the sense of a voice that can be molded by different training or "conditioning" processes, and that can, likewise, be flexibly combined and recombined after it is recorded. Neoliberal logics of voice do not do away with the premises of modern ideologies, but rather shift them to the demands of a new context. Modern notions of will and intention are refigured as personality, uniqueness, and creativity, features that can distinguish one voice from others in the context of a competitive market of voices. The modern notion of voice as expression of inner self is refigured as the demand of presenting an accessible self, communicating with one's audience and learning the skills of a new kind of "performance."

Many young singers see the new era of playback singing as an opening up, a freeing from the restrictions of gendered respectability that were embedded in the older conventions of playback singing. While not discounting their perspective, I have attempted here to capture the complexity of a shift that might be too easily celebrated as liberating. Modern ideologies of voice, and their neoliberal reframings, are extremely familiaralmost commonsense-- to those of us who operate within a Euro-American context with its widely circulating metaphors of "voice" as choice, personality, uniqueness, freedom, and communication. As such ideas gain currency in different world contexts, it is important to ask what kinds of subjects and practices they enable, and what previously existing possibilities they displace.

\section{Acknowledgements}

The research for this article was conducted in Chennai from Oct 2009-Jan 2010 and Nov 2012-Jan 2013, funded by the American Institute of Indian Studies, a Fulbright-Nehru research grant, and a fellowship from the American Council of Learned Societies. I thank the following individuals who took time from their busy Kollywood lives to speak with me: Anupamaa Krishnaswami, Satish Chakravarty, Chinmayi Sripada, Rahul, Ranjit, Swetha Mohan, Suchitra, "Malgudi" Subha, Ananth Vaidyanathan, P. Susheela, K.S. Chitra, Sunitha Sarathy. I thank Laura Kunreuther and Javier Leon for their helpful comments on earlier drafts of this article.

\section{References}

Booth, Gregory. 2011. "Preliminary Thoughts on Hindi Popular Music and Film Production: India's Culture Industry(ies), 1970-2000. South Asian Popular Culture 9(2): 215-221.

Chakraborty, Pallabi. 2011. Global Dancing in Kolkata. In A Companion to the Anthropology of India, I. Clark-Decès, ed. Oxford, UK: Wiley-Blackwell.

Fernandes, Leela. 2006. India's New Middle Class: Democratic Politics in an Era of Economic Reform. Minneapolis: University of Minnesota Press.

Ganti, Tejaswini. 2012. Producing Bollywood: Inside the Contemporary Hindi Film Industry. Durham, NC: Duke University Press.

Gershon, Ilana. 2011. "Neoliberal Agency." Current Anthropology 52(4): 537-555. 
Getter, Joseph and B. Balasubrahmaniyan. 2008. "Tamil Film Music: Sound and Significance." In Global Soundtracks: Worlds of Film Music. M. Slobin, ed. pp 114151. Middletown, CT: Wesleyan University Press.

Indraganti, Kiranmayi. 2012. "Of 'Ghosts' and Singers: Debates around Singing Practices of 1940s Indian Cinema." South Asian Popular Culture 10(3): 296-306. Jakobson, Roman. 1987. "Linguistics and Poetics." In Language in Literature. K. Pomorska and S. Rudy, eds, pp 62-94. Cambridge, MA: Harvard University Press. Jenkins, Roy. (1999) Democratic Politics and Economic Reform in India. Cambridge: Cambridge University Press.

Kunreuther, Laura. 2006. "Technologies of the Voice: FM Radio, Telephone, and the Nepali Diaspora in Kathmandu." Cultural Anthropology 21(3): 323-353.

---- 2010. “Transparent Media: Radio, Voice, and Ideologies of Directness in Postdemocratic Nepal.” Journal of Linguistic Anthropology 20(2): 334-351.

Kvetko, Peter. 2004. “Can the Indian Tune Go Global?” The Drama Review 48(4): 183191.

Lakshmi, C.S. 1990. "Mother, Mother-Community and Mother-Politics in Tamil Nadu." Economic and Political Weekly 25(43): WS 72-83.

Lukose, Ritty. 2009. Liberalization's Children: Gender, Youth, and Consumer Citizenship in Globalizing India. Durham, NC: Duke University Press.

Majumdar, Neepa. 2001. "The Embodied Voice: Song Sequences and Stardom in Popular Hindi Cinema." In Soundtrack Available: Essays on Film and Popular Music, eds., A. Knight and P. Wojcik, pp 161-181. Durham, NC: Duke University Press.

Mathai, Kamini. 2009. A.R. Rahman: The Musical Storm. New Delhi: Penguin Books India.

Mazzarella, William. 2003. Shoveling Smoke: Advertising and Globalization in Contemporary India. Durham, NC: Duke University Press.

---- 2013. Censorium: Cinema and the Open Edge of Mass Publicity. Durham, NC: Duke University Press.

McGuire, Meredith. 2011. "How to Sit, How to Stand: Bodily Practice and the New Middle Class." In A Companion to the Anthropology of India, I. Clark-Decès, ed, Oxford, UK: Wiley-Blackwell.

Nakassis, Constantine. 2010. Youth and Status in Tamil Nadu. PhD dissertation, University of Pennsylvania.

Oza, Rupal. 2006. The Making of Neoliberal India: Nationalism, Gender, and the Paradoxes of Globalization. New York: Routledge.

Rajagopal, Arvind. 1999. "Thinking Through Emerging Markets: Brand Logics and the Cultural Forms of Political Society In India.” Social Text 60(17): 131-149.

--- 2001. Politics After Television: Hindu Nationalism and the Reshaping of the Public in India. Cambridge: Cambridge University Press.

Ramaswamy, Sumathi. 1997. Passions of the Tongue: Language Devotion in Tamil India, 1891-1970. Berkeley: University of California Press.

Sarrazin, Natalie. 2008. Songs from the Heart: Musical Coding, Emotional Sentiment, and Transnational Sonic Identity in India's Popular Film Music. In Global Bollywood, eds., Anandam Kavoori and Asin Punethambekar, pp 203-219. New York: NYU Press. 
Srivastava, Sanjay. 2006. "The Voice of the Nation and the Five-Year Plan Hero: Speculations on Gender, Space, and Popular Culture." In Fingerprinting Popular Culture: The Mythic and the Iconic in Indian Cinema, pp 122-155. New Delhi: OUP. Sudakar, Yazh. n.d. "Susheelavin Kural" [Susheela's Voice]. http://psusheela.org/articles/yazh_ps.html (accessed April 24, 2013)

Taylor, Charles. 1992. Sources of the Self: The Making of Modern Identity. Cambridge: Cambridge University Press.

Taylor, Jessica. 2009. "Speaking Shadows: A History of the Voice in the Transition from Silent to Sound Film in the United States." Journal of Linguistic Anthropology 19(1): $1-20$.

Urciuoli, Bonnie. 2008. "Skills and Selves in the New Workplace." American Ethnologist 35(2): 211-228.

Zuberi, Nabeel. 2002. "India Song: Popular Music Genres Since Economic Liberalization." In Popular Music Studies, D. Hesmondhalgh, ed. pp 238-250. New York: Oxford University Press.

${ }^{1}$ In the U.S., by contrast, the emphasis, particularly during the transition from silent to sound film, was on maintaining an illusion of bodily continuity between actress and voice. See Taylor 2009 for a discussion of the U.S. context.

${ }^{2}$ P. Susheela, interview with author, June 2002.

${ }^{3}$ Anupamaa Krishnaswami, interview with author, Dec 3, 2009. Also see Mathai 2009, pp 73-74 for a description of Rahman's quest for new voices in making the music for the film Roja.

${ }^{4}$ The film and particularly this scene refer to the 1948 film Chandralekha, about a dancer, played by the actress T.R. Rajakumari, who herself came from a devadasi background. This scene visually evokes the famous "drum dance" near the climax of the 1948 film, during which the hero comes to Chandralekha's rescue and helps her escape from the villain's palace. Both the 1948 film and the 1993 film can be seen as playing with the idea of the power of female performance.

${ }^{5}$ http://www .youtube.com/wathc?v=b-1a5mB-Mq8 (A.R. Rahman Chennai Unity of Light Concert, accessed April 17, 2013).

${ }^{6}$ Chinmayi Sripada, interview with author, Dec 11, 2009.

${ }^{7}$ Swetha Mohan, interview with author, Dec 21, 2012.

${ }^{8}$ Rahul, interview with author, Dec 8, 2012.

${ }^{9}$ Ranjit, interview with author, Dec 10, 2012.

${ }^{10}$ K.S. Chitra, interview with author, Jan 5, 2010.

${ }^{11}$ Satish Chakravarty, interview with author, Nov 1, 2009.

${ }^{12}$ A formal and respectful way of saying "greetings."

${ }^{13}$ Machchan is the Tamil word for brother-in-law, used as a term of reference and as a term of address. It is extended as an informal term of address most often used among young men. As such, something like 'dude,' the term can index this kind of informality even when it is used by women. In the imaginary scenario Subha depicts here, the word is being used by a female singer to greet her male friends/colleagues in the studio. 
${ }^{14}$ Subha, interview with author, Dec 3, 2012.

${ }^{15}$ The young singer here uses the phrase "come naturally to them" to allude to classbased, in addition to gender-based, distinctions. "Hanging out" without an apparent purpose either in public or in private spaces such as the studio, is very much associated with the habitus of the new upper-middle class in India and would not be part of an older set of acceptable "middle class" practices (McGuire 2011).

16 http://www.youtube.com/watch?v=0NMyrf9gsWw (Airtel Super Singer Junior 3 Performance Round, accessed Oct 24, 2012).

${ }^{17}$ Ilana Gershon suggests that the neoliberal perspective "creates a new status for the expert - the expert becomes someone with the unique reflexive role of explaining to other autonomous entities how to manage themselves more successfully $(2011,542)$.

${ }^{18}$ For example, "Personality Development and Enhancement" (PDE), a new industry in the Indian post-liberalization economy, can be seen as part of this (McGuire 2011).

${ }^{19}$ Ananth Vaidyanathan, interview with author, Dec 7, 2012. 